\title{
A 69-year-old man with a painful vesicular rash
}

\author{
Derek R. MacFadden MD, Wayne L. Gold MD
}

A previously healthy 69-year-old man presents to his primary care physician with a painful vesicular eruption of 24 hours' duration. He recalls that his 65-year-old brother had a similar rash one year earlier, which had been diagnosed as shingles. He wants to know what can be done to prevent the development of the severe pain experienced by his brother and whether his 62-year-old wife would be a candidate for the "shingles vaccine."

\section{How do we know if this patient has her- pes zoster (shingles)?}

Herpes zoster, caused by varicella zoster virus, most commonly presents as a unilateral dermatomal, vesicular eruption. A sensory prodrome, ranging from minor tingling to severe pain, precedes the rash by $1-5$ days. ${ }^{1,2}$ Typically, the rash involves a single dermatome and does not cross the midline. The presence of the characteristic rash (Figure 1) is sufficient to allow for clinical diagnosis. ${ }^{1,2}$

\section{What risk factors does this patient have for herpes zoster?}

After acute infection by varicella zoster virus, typically as chickenpox in childhood, the virus remains dormant in the dorsal nerve root ganglia. ${ }^{1,2}$ When viral suppression is interrupted by mechanisms that impair cell-mediated immunity, varicella zoster virus can propagate distally along sensory neurons to cause shingles. The most common risk factor for reactivation, and the one most likely responsible for this patient's presentation, is advancing age (immunosenescence). The incidence of herpes zoster dramatically increases with age, with an incidence of $1.3-4.2$ cases per 1000 personyears in those aged less than 60 years to 6.0 10.7 cases per 1000 person-years in those aged 60 or older. ${ }^{3}$ Other risk factors include HIV infection, hematologic malignancy and the use of drugs that impair cellular immune function, such as corticosteroids. ${ }^{1,2}$

\section{How should this patient's herpes zoster be treated?}

Pain, as described by this patient, is the most common morbidity associated with herpes zoster. $^{1,2}$ In a population-based study of herpes zoster before the introduction of zoster vaccine, $18 \%$ of patients reported pain lasting more than 30 days following onset of the rash, termed postherpetic neuralgia. ${ }^{3}$ The incidence and severity of postherpetic neuralgia increases with age and occurs in up to $33 \%$ of adults with zoster over 79 years of age. ${ }^{3}$ Starting oral antiviral therapy within 72 hours of onset of the rash reduces the severity of acute pain. ${ }^{1,2}$ A metaanalysis of 4 randomized placebo-controlled trials comparing acyclovir to placebo in 691 patients aged 50 years or older showed a reduction in the median time to complete resolution of pain from 101 days to 41 days. ${ }^{4}$ A more recent meta-analysis of 4 randomized placebo-

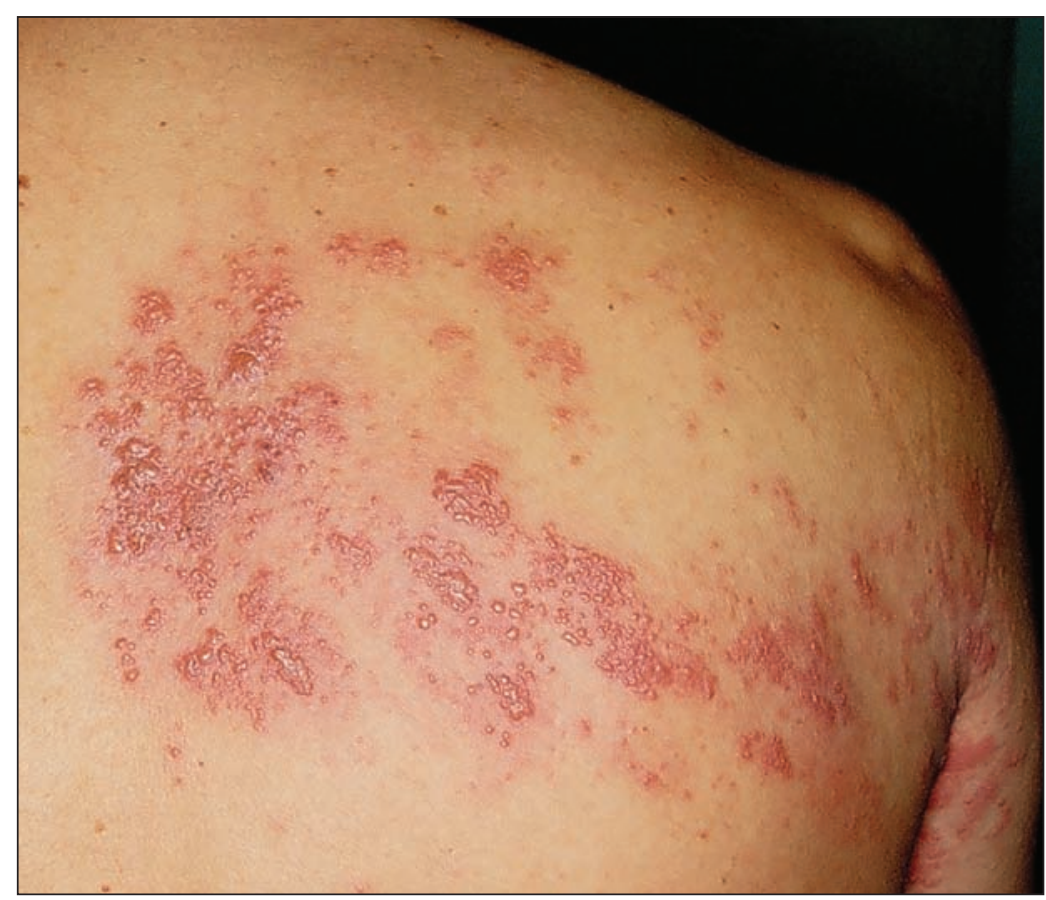

Figure 1: A unilateral vesicular rash in a right-sided T4 dermatomal distribution.
Competing interests: None declared.

This article has been peer reviewed.

Correspondence to:

Wayne L. Gold, wayne.gold@uhn.on.ca

CMAJ 2012. DOI:10.1503 /cmaj.120480 
controlled trials involving 692 patients showed a relative risk of postherpetic neuralgia at 1 month following the onset of rash of 0.83 (95\% confidence interval [CI] 0.71-0.96) in patients receiving acyclovir. This benefit, however, was no longer present at four and six months following the onset of rash. ${ }^{5}$ Methodologic differences in the inclusion and analysis of individual studies in the meta-analyses may account for some of the difference in outcomes. Therefore, uncertainty remains regarding the impact of antiviral therapy on pain outcomes in patients with herpes zoster. When prescribing antiviral therapy, valacyclovir and famciclovir may be superior to acyclovir in achieving complete cessation of pain. ${ }^{2,6}$ For cases of V1 dermatomal zoster (zoster ophthalmicus), antiviral therapy should always be initiated, even if the patient presents beyond 72 hours after the onset of rash, to reduce late ocular complications. ${ }^{2}$ Treatment regimens are presented in Table $1 .^{1,7}$

One small randomized placebo-controlled trial suggested the possible benefit of amitriptyline in the prevention of postherpetic neuralgia, when prescribed at presentation; however, the use of antivirals in this trial was not standardized, making the results difficult to interpret. ${ }^{8}$ Two large randomized placebo-controlled trials assessing anti-inflammatory therapy with corticosteroids in combination with acyclovir showed no effect on the incidence or duration of postherpetic neuralgia. ${ }^{49}$

Table 1: Medications used in the treatment of herpes zoster and postherpetic neuralgia

\begin{tabular}{|c|c|c|c|}
\hline Drug & Dose and duration & Adverse events* & $\begin{array}{l}\text { Daily } \\
\text { cost, \$† }\end{array}$ \\
\hline \multicolumn{4}{|c|}{ Acute herpes zoster‡ } \\
\hline Acyclovir & $\begin{array}{l}800 \mathrm{mg} \text { five times } \\
\text { daily for } 7 \mathrm{~d}^{1}\end{array}$ & $\begin{array}{l}\text { - Common: nausea, vomiting, diarrhea } \\
\text { - Severe: acute kidney injury, cytopenia, } \\
\text { Stevens-Johnson syndrome }\end{array}$ & 6.34 \\
\hline Valacyclovir & $\begin{array}{l}1000 \mathrm{mg} \text { three } \\
\text { times daily for } 7 \mathrm{~d}^{1}\end{array}$ & $\begin{array}{l}\text { - Common: headache, diarrhea, nausea } \\
\text { - Severe: acute kidney injury, thrombotic } \\
\text { thrombocytopenia purpura, cytopenia, } \\
\text { hepatitis }\end{array}$ & 5.09 \\
\hline Famciclovir & $\begin{array}{l}500 \mathrm{mg} \text { three times } \\
\text { daily for } 7 \mathrm{~d}^{1}\end{array}$ & $\begin{array}{l}\text { - Common: headache, nausea, confusion } \\
\text { - Severe: Stevens-Johnson syndrome, hepatitis, } \\
\text { thrombocytopenia }\end{array}$ & 5.07 \\
\hline \multicolumn{4}{|c|}{ Postherpetic neuralgia } \\
\hline Amitriptyline & $12.5-200 \mathrm{mg} / \mathrm{d}^{7}$ & $\begin{array}{l}\text { - Common: anticholinergic effects (dry mouth, } \\
\text { urinary retention, confusion) } \\
\text { - Severe: cardiac arrhythmia, cytopenia }\end{array}$ & $0.12-0.96$ \\
\hline Nortriptyline & $30-120 \mathrm{mg} / \mathrm{d}^{7} \S$ & $\begin{array}{l}\text { - Common: anticholinergic effects (dry mouth, } \\
\text { urinary retention, confusion) } \\
\text { - Severe: cardiac arrhythmia, cytopenia }\end{array}$ & $0.15-0.60$ \\
\hline Gabapentin & $1800-3600 \mathrm{mg} / \mathrm{d}^{7} \rrbracket$ & $\begin{array}{l}\text { - Common: somnolence, fatigue, ataxia } \\
\text { - Severe: leukopenia, Stevens-Johnson } \\
\text { syndrome }\end{array}$ & $1.55-3.09$ \\
\hline Pregabalin & $300 \mathrm{mg} / \mathrm{d}^{7} * *$ & $\begin{array}{l}\text { - Common: dizziness, somnolence, peripheral } \\
\text { edema } \\
\text { - Severe: acute kidney injury, congestive heart } \\
\text { failure }\end{array}$ & 2.23 \\
\hline Divalproate & $1000 \mathrm{mg} / \mathrm{d}^{7}$ & $\begin{array}{l}\text { - Common: nausea, vomiting, gastrointestinal } \\
\text { upset } \\
\text { - Severe: drug-induced lupus, cytopenia, } \\
\text { pancreatitis, hepatitis }\end{array}$ & 2.18 \\
\hline Capsaicin & $0.075 \%$ cream $^{7}+\dagger$ & - Common: local burning, coughing & $\begin{array}{l}\text { Market } \\
\text { price }\end{array}$ \\
\hline \multicolumn{4}{|c|}{$\begin{array}{l}\text { *The adverse events listed are not comprehensive but are a representative sample based on selections from monographs at } \\
\text { www.e-therapeutics.ca } \\
\text { †Average daily cost in Canadian dollars (excluding dispensing fees) based on data from the Ontario Drug Formulary at } \\
\text { www.health.gov.on.ca/english/providers/program/drugs/odbf_mn.html } \\
\text { fAntivirals (acyclovir, valacyclovir or famciclovir) should be started within } 72 \mathrm{~h} \text { of onset of rash. } \\
\text { §Titrated to maximum tolerable dose. } \\
\text { qTitrated over a 4-week dose escalation period. } \\
\text { **Titrated over a 1-week dose escalation period. } \\
\text { ††Typically administered four times daily or by a } 60 \text {-minute high-concentration patch. }\end{array}$} \\
\hline
\end{tabular}




\section{If postherpetic neuralgia develops, how can it be treated?}

Postherpetic neuralgia often requires complex analgesic management. Common medications used for its treatment, taken alone or in combination, are presented in Table 1., ${ }^{1,7}$ There are limited evidence-based data to suggest a benefit of one analgesic regimen over another; ${ }^{7}$ typically, tricyclic antidepressants or anticonvulsants are used as first-line agents. For the individual patient, both cost and adverse outcomes should guide the choice of agent. Topical capsaicin can also be used alone or in combination with oral agents. ${ }^{7}$ In refractory cases, referral to a specialized pain management centre should be considered. ${ }^{2}$

\section{Should the patient's wife receive the her- pes zoster vaccine?}

A randomized placebo-controlled trial involving 38546 adults aged 60 years and older showed that zoster vaccine reduced the incidence of herpes zoster by $51.3 \%$ (11.1 cases per 1000 person-years in the placebo arm, and 5.4 cases per 1000 personyears in the vaccine arm; $p<0.001$ ) and decreased the incidence of postherpetic neuralgia by $67 \%$ (1.38 cases per 1000 person-years in the placebo arm, and 0.46 cases per 1000 person-years in the vaccine arm; $p<0.001) .^{10}$ The Canadian National Advisory Committee on Immunization currently recommends administration of zoster vaccine to adults over 60 years of age, which includes this patient's wife. These recommendations may change, because a recent randomized placebocontrolled trial involving 22439 adults aged 50-59 years showed that zoster vaccine reduced the incidence of herpes zoster by $69.8 \%$ (6.57 cases per 1000 person-years in the placebo arm, and 1.99 cases per 1000 person-years in the vaccine arm; 95\% CI 54.1\%-80.6\%). ${ }^{11}$ Contraindication to vaccination includes immunodeficiency states. Zoster vaccine is not indicated for patients with active zoster or for the treatment of postherpetic neuralgia.

\section{The case revisited}

After herpes zoster was diagnosed by his primary care physician, the patient was prescribed a one-week course of valacyclovir. Ongoing pain required treatment with gabapentin, which was eventually stopped. His wife received the herpes zoster vaccine.

\section{References}

1. Wareham DW, Breuer J. Herpes zoster. BMJ 2007;334:1211-5.

2. Gnann JW Jr., Whitley RJ. Clinical practice. Herpes zoster. $N$ Engl J Med 2002;347:340-6.

3. Yawn BP, Saddier P, Wollan PC, et al. A population-based study of the incidence and complication rates of herpes zoster before zoster vaccine introduction. Mayo Clin Proc 2007;82: 1341-9.

4. Wood MJ, Johnson RW, McKendrick MW, et al. A randomized trial of acyclovir for 7 days and 21 days with and without prednisolone for treatment of acute herpes zoster. $N$ Engl J Med 1994;330:896-900.

5. Li Q, Chen N, Yang J, et al. Antiviral treatment for preventing postherpetic neuralgia. Cochrane Database Syst Rev 2009;(2): CD006866.

6. McDonald EM, de Kock J, Ram FS. Antivirals for management of herpes zoster including opthalmicus: a systematic review of high-quality randomized controlled trials. Antivir Ther 2012;17: 255-64.

7. Edelsberg JS, Lord C, Oster G. Systematic review and metaanalysis of efficacy, safety, and tolerability data from randomized controlled trials of drugs used to treat postherpetic neuralgia. Ann Pharmacother 2011;45:1483-90.

8. Bowsher D. The effects of pre-emptive treatment of postherpetic neuralgia with amitriptyline: a randomized, double-blind, placebo-controlled trial. J Pain Symptom Manage 1997;13: 327-31.

9. Whitley RJ, Weiss H, Gnann JW, et al. Acyclovir with and without prednisone for the treatment of herpes zoster: a randomized, placebo-controlled trial. The National Institute of Allergy and Infectious Diseases Collaborative Antiviral Study Group. Ann Intern Med 1996;125:376-83.

10. Oxman MN, Levin MJ, Johnson GR, et al. A vaccine to prevent herpes zoster and postherpetic neuralgia in older adults. $N$ Engl J Med 2005;352:2271-84.

11. Schmader KE, Levin MJ, Gnann JW Jr., et al. Efficacy, safety, and tolerability of herpes zoster vaccine in persons aged 50-59 years. Clin Infect Dis 2012;54:922-8.

Affiliations: From the Department of Medicine (MacFadden), University of Toronto; and the Division of Infectious Diseases (Gold), University Health Network, Toronto, Ont.

Contributors: Both authors contributed to drafting, revising and critically reviewing the manuscript and gave final approval of the version submitted for publication.

Decisions is a series that focuses on practical evidence-based approaches to common presentations in primary care. The articles address key decisions that a clinician may encounter during initial assessment. The information presented can usually be covered in a typical primary care appointment. Articles should be no longer than 650 words, may include one box, figure or table and should begin with a very brief description ( 75 words or less) of the clinical situation. The decisions addressed should be presented in the form of questions. A box providing helpful resources for the patient or physician is encouraged. 